.... Bardak, Sozen, Kayahan, Bardak: The Impact of Nanoparticles and Moisture Content...

Timuçin Bardak, Eser Sozen², Kadir Kayahan', Selahattin Bardak

\title{
The Impact of Nanoparticles and Moisture Content on Bonding Strength of Urea Formaldehyde Resin Adhesive
}

\section{Utjecaj nanočestica i sadržaja vode u drvu na čvrstoću lijepljenja urea-formaldehidnim ljepilom}

\author{
Original scientific paper $\bullet$ Izvorni znanstveni rad \\ Received-prispjelo: 29. 9. 2017. \\ Accepted-prihvaćeno: 13. 6. 2018. \\ UDK: $630 * 812.222 ; 630 * 824.328 ; 630 * 824.43$ \\ doi:10.5552/drind.2018.1755
}

\begin{abstract}
Wood and wood products have been used in different environmental conditions. Moisture content $(M C)$ and relative humidity $(R H)$ are key parameters for these conditions and bonding strength. Nanotechnology has paved the way to more durable adhesives. An experimental study was conducted to examine the effects of various nanoparticles and moisture content on bonding strength of urea formaldehyde (UF) resin adhesive. In this study, nanosilicon dioxide $\left(\mathrm{SiO}_{2}\right)$ and titanium dioxide $\left(\mathrm{TiO}_{2}\right)$ were blended with UF. Nanoparticle reinforced adhesives were processed at different nano fillers concentrations ( $0.5 \%$ and $1 \%$ ) and each adhesive was tested at the moisture content of $0 \%, 12 \%, 18 \%$ and $25 \%$. According to the results of bonding strength tests, contained nano-SiO, adhesives showed better bonding strengths as compared to the control (pure UF) and contained nano$\mathrm{TiO}_{2}$ adhesives. The highest bonding strength has been determined at $12 \%$ wood moisture in all specimens. Increasing the moisture content has decreased bonding strength of all samples including control samples. This study showed that nano ( $\mathrm{SiO}_{2}$ and $\mathrm{TiO}_{2}$ ) particles have improved the bonding strength of pure UF. Besides, the addition of nano-SiO ${ }_{2}$ and nano-TiO ${ }_{2}$ changed the physicochemical properties of UF adhesive by XRD test. The novelty of this study was to demonstrate that nanoparticles $\left(\mathrm{SiO}_{2}\right.$ and $\mathrm{TiO}_{2}$ ) could be beneficial for the bonding strength of UF adhesive in harsh environmental conditions.
\end{abstract}

Keywords: nanoparticles, urea formaldehyde, moisture content, lap joint shear strength, bonding strength

SAŽETAK • Drvo i drvni proizvodi upotrebljavaju se u različitim okolišnim uvjetima. Sadržaj vode u drvu (MC) $i$ relativna vlažnost zraka $(R H)$ ključni su parametri koji utječu na čvrstoću lijepljenja drva u određenim okolišnim

\footnotetext{
Authors are Ph.D. and lecturer at Department of Furniture and Decoration, Vocational Schools, Bartin University, Turkey. ${ }^{2}$ Author is research assistant at Department of Forest Industrial Engineering, Faculty of Forestry, Bartin University, 74100, Turkey. ${ }^{3}$ Author is assistant professor at Department of Industrial Engineering, Faculty of Engineering and Architecture, Sinop University, Turkey.

Autori su doktor znanosti i predavač Odjela za namještaj i opremanje, Stručna škola, Sveučilište u Bartinu, Bartin, Turska. ${ }^{2}$ Autor je znanstveni asistent Odjela za industrije na bazi šuma, Šumarski fakultet, Sveučilište u Bartinu, Bartin, Turska. ${ }^{3}$ Autor je docent Odjela za industrijski inženjering, Fakultet inženjerstva i arhitekture, Sveučilište u Sinopu, Turska.
} 
uvjetima. Nanotehnologija je otvorila put za proizvodnju postojanijih ljepila. U radu su prikazani rezultati eksperimentalnog istraživanja utjecaja različitih nanočestica i sadržaja vode u drvu na čvrstoću lijepljenja urea-formaldehidnim ljepilom (UF). U istraživanju su nanosilikonski dioksid ( $\mathrm{SiO}_{2}$ ) i titanijev dioksid $\left(\mathrm{TiO}_{2}\right.$ ) pomiješani s UF ljepilom. Ljepila ojačana nanočesticama pripremljena su uz dodatak različitih koncentracija nanopunila $(0,5$ i 1 \%), a svako je ljepilo ispitano na drvu različitog sadržaja vode u njemu: 0, 12, 18 i $25 \%$. Iz rezultata ispitivanja čvrstoće lijepljenja može se uočiti da su ljepila s nanočesticama $\mathrm{SiO}_{2}$ pokazala veću čvrstoću lijepljenja u usporedbi s kontrolnim uzorcima (lijepljenih čistim UF ljepilom) is uzorcima lijepljenim ljepilom ojačanim nanočesticama $\mathrm{TiO}_{2}$. Najveća čvrstoća lijepljenja postignuta je na uzorcima sa sadržajem vode od $12 \%$. Uz povećan sadržaj vode smanjila se čvrstoća lijepljenja svih uzoraka, uključujući i kontrolne. Na temelju rezultata istraživanja može se zaključiti da se dodavanjem nanočestica $\left(\mathrm{SiO}_{2}\right.$ i TiO $\mathrm{T}_{2}$ ljepilu poboljšava čvrstoća zalijepljenog spoja odnosno da se tim ljepilom postiže čvršće lijepljenje nego čistim UF ljepilom. Osim toga, uz pomoć XRD testa utvrđeno je da su se dodavanjem nanočestica $\mathrm{SiO}_{2}$ i TiO ${ }_{2}$ promijenila fizikalno-kemijska svojstva UF ljepila. Istraživanje je potvrdilo da nanočestice ( $\mathrm{SiO}_{2}$ i TiO T $_{2}$ mogu biti korisne za čvrstoću lijepljenja drva UF ljepilom u nepovoljnim okolišnim uvjetima.

Ključne riječi: nanočestice, urea-formaldehid, sadržaj vode, smicajna čvrstoća spoja, čvrstoća lijepljenja

\section{INTRODUCTION}

1. UVOD

The application of nanotechnology in wood industry is on the rise. Adhesive bonding is generally used in various applications due to its several benefits such as the large area of bonding, possibility of joining different materials (Katnam et al., 2011; Ghosh et al. 2016). Bonding technology has been developing for a long time. Urea-formaldehyde (UF) resins are the most generally used adhesives in the forest industry (Lubis et al., 2017). UF resin adhesive has a lot of advantages such as good performance in the panel, solubility in water and lower cost. However, there are disadvantages to using UF resin adhesives as well; they have lower resistance to excess moisture and formaldehyde emission from the panels (Park et al., 2009). Moisture absorption is indicated as one of the important causes of impairing the mechanical properties of polymers because physical changes occur at microscopic levels in composites (Mieloszyk and Ostachowicz, 2017).

For many years, nanomaterials have received much interest for application in adhesives due to high specific surface areas and unique mechanical properties (Heon Kwon et al.,2015). Nanocomposites are formed by the dispersion of nanoparticles into the polymer. They have unique properties, such as high heat resistance, toughness and stiffness (Bauer and Mehnert, 2005; Salla et al., 2012). Scientific and industrial interest has focused on polymer nanocomposites (Dorigato and Pegoretti, 2011). There are many studies that considered the development of nanocomposites (Yang et al., 2006; Wang et al., 2011). However, studies on the assessment of nanoparticles in the adhesive industry are limited. Adhesives have an important place in wood industry. The quality and durability of a wooden product primarily depend on the quality of its adhesive bonding. Nanoparticles can help to produce enhanced wood products (Bardak et al., 2017).

Many difficulties in applying wood as an engineering material arise from variations in moisture content. This situation also has a negative effect on the adhesive performance. In this study, bonding perfor- mances of urea formaldehyde adhesive at different equilibrium moisture contents (EMC) of wood were determined.

\section{MATERIALS AND METHODS 2. MATERIJALI I METODE}

Urea formaldehyde adhesive was obtained from SFC Integrated Forestry Products Company (Turkey). It has a solid content of $60 \%, \mathrm{pH} \mathrm{8.0,} \mathrm{and} \mathrm{density}$ $1.260 \mathrm{~g} / \mathrm{cm}^{3}$. Nano- $\mathrm{SiO}_{2}$ and nano- $\mathrm{TiO}_{2}$ were supplied by MkNANO (Canada). Properties of nanoparticles used in the research are presented in Table 1. In the study, oak (Quercus robur), with the specific gravity of $0.65 \mathrm{~g} / \mathrm{cm}^{3}$, was used as wood material. Modulus of rapture $(M O R)$ and modulus of elasticity $(M O E)$ were determined in bending test according to the procedures described in TS 2474 (1976). MOR and MOE values of wood material were found to be $87 \mathrm{MPa}$ and 12350 $\mathrm{MPa}$, respectively.

Table 1 Properties of nanoparticles used in the research Tablica 1. Svojstva nanočestica upotrijebljenih u istraživanju

\begin{tabular}{|l|c|c|}
\hline Properties / Svojstvo & $\mathbf{S i O}_{2}$ & $\mathbf{T i O}_{2}$ \\
\hline $\begin{array}{l}\text { Nanoparticle size } \\
\text { Veličina nanočestice }\end{array}$ & $15 \mathrm{~nm}$ & $50 \mathrm{~nm}$ \\
\hline $\begin{array}{l}\text { Specific surface area } \\
\text { Specifična površina }\end{array}$ & $650 \mathrm{~m}^{2} / \mathrm{g}$ & $150 \mathrm{~m}^{2} / \mathrm{g}$ \\
\hline Purity / Čistoća, \% & 99 & 99 \\
\hline Dissociation / Disocijacija & $\begin{array}{c}\text { Hydrophilic } \\
\text { hidrofilna }\end{array}$ & $\begin{array}{c}\text { Hydrophilic } \\
\text { hidrofilna }\end{array}$ \\
\hline
\end{tabular}

\subsection{Preparation of adhesives}

\subsection{Priprema ljepila}

Nano- $-\mathrm{SiO}_{2}$ and nano- $\mathrm{TiO}_{2}$ were added to urea formaldehyde adhesive at the rate of $0.5 \%$ and $1 \%$ (according to solid content), separately. The UF resins reinforced with nanoparticles were mixed with a 30 min mechanical stirrer. Then, $1.5 \%$ ammonium chloride was added as a hardener to UF resins reinforced with nanoparticles. Sample codes, nanoparticle types and rates are given in Table 2. 
Table 2 Sample codes, nanoparticle types and rates used in the study

Tablica 2. Oznake uzoraka te vrsta i udio nanočestica u ljepilu

\begin{tabular}{|l|c|c|}
\hline $\begin{array}{l}\text { Sample codes } \\
\text { Oznaka uzorka }\end{array}$ & $\begin{array}{c}\text { Nanoparticle } \\
\text { type } \\
\text { Vrsta nanočestica }\end{array}$ & $\begin{array}{c}\text { Nanoparticle rate } \\
\text { Udio nanočestica } \\
\%\end{array}$ \\
\hline Pure UF & - & - \\
\hline $0.5 \% \mathrm{SiO}_{2}+\mathrm{UF}$ & $\mathrm{SiO}_{2}$ & 0.5 \\
\hline $1 \% \mathrm{SiO}_{2}+\mathrm{UF}$ & $\mathrm{SiO}_{2}$ & 1 \\
\hline $0.5 \% \mathrm{TiO}_{2}+\mathrm{UF}$ & $\mathrm{TiO}_{2}$ & 0.5 \\
\hline $1 \% \mathrm{TiO}_{2}+\mathrm{UF}$ & $\mathrm{TiO}_{2}$ & 1 \\
\hline
\end{tabular}

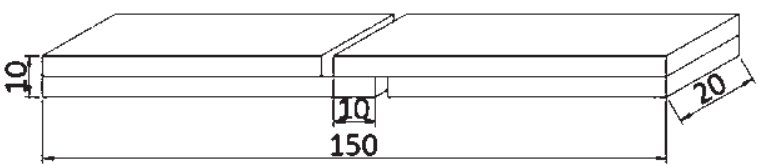

Figure 1 Dimensions of shear strength test sample (mm) Slika 1. Dimenzije uzorka za ispitivanje smicajne čvrstoće

\subsection{Bonding strength}

\section{2. Čvrstoća lijepljenja}

The obtained UF mixings were applied in the amount of $180-190 \mathrm{~g} / \mathrm{m}^{2}$ to one surface of the samples with the dimensions of $200 \times 50 \times 5 \mathrm{~mm}$. Then, samples were pressed at $115 \pm 5{ }^{\circ} \mathrm{C}$ temperature and $1 \mathrm{~N} /$ $\mathrm{mm}^{2}$ pressure for 7 minutes by using a hydraulic test machine. Specimens were then removed from press, and they were cut to dimensions of $150 \times 20 \times 5 \mathrm{~mm}$ according to EN 302-1 Norm. Figure 1 shows the dimensions of shear test samples.

Samples were kept at four different EMC air conditions $(0 \%, 12 \%, 18 \%$, and $25 \%)$ by using conditioning chamber. To determine EMC, moisture control samples (MCSs) were placed to conditioning cabinet for every different moisture content. Table 3 shows air conditions for $0 \%, 12 \%, 18 \%$, and $25 \%$ EMCs.

The samples were tested in a device with maximum load capacity of $100 \mathrm{kN}$. Shear strength was calculated from Equation (1).

$$
\tau=\frac{F \max }{A}
$$

Where $\tau$ is shear strength $\left(\mathrm{N} / \mathrm{mm}^{2}\right), F \max$ is maximum load, and $A$ is bonding surface of sample $(10 \mathrm{x}$ $20=200 \mathrm{~mm}^{2}$ ). All shear strength data were analyzed by

Table 3 Air conditions and reached EMCs

Tablica 3. Svojstva zraka i postignuti ravnotežni sadržaji vode u drvu

\begin{tabular}{|c|c|c|c|}
\hline $\begin{array}{c}\text { Temperature } \\
\text { Temperatura } \\
{ }^{\circ} \mathrm{C}\end{array}$ & $\begin{array}{c}\text { Relative } \\
\text { humidity } \\
\text { Relativna } \\
\text { vlažnost zraka } \\
\%\end{array}$ & $\begin{array}{c}\text { Time } \\
\text { Vrijeme } \\
\text { days } \\
\text { dani }\end{array}$ & $\begin{array}{c}\text { Moisture } \\
\text { content } \\
\text { Sadržaj vode } \\
u \text { drvu } \\
\%\end{array}$ \\
\hline $103 \pm 2$ & 0 (in oven) & 3 & 0 (Oven dry) \\
\hline $20 \pm 2$ & 65 & 2 & 12 \\
\hline $15 \pm 2$ & 80 & 4 & 18 \\
\hline $10 \pm 2$ & 90 & 10 & 25 \\
\hline
\end{tabular}

using SPSS software. ANOVA was used for establishing the differences between the groups.

XRD graph was made on a Rigaku Smartlab (Chech Republic) with Ni-filtered Cu Ka (1.540562 Å) radiation source operated at $45 \mathrm{kV}$ voltage and $40 \mathrm{~mA}$ electric current. The viscosities of the adhesive were measured by Brookfield CAP 2000 + viscometer, according to the ASTM D2256-11 standard. All gel-time measurements were made at a temperature of $100{ }^{\circ} \mathrm{C}$ in a trace of water.

\section{RESULTS AND DISCUSSION}

\section{REZULTATI I RASPRAVA}

Table 4 shows that the addition of nanoparticles to UF adhesive generally yields a significant change in bonding strength at different moisture contents.

The results clearly show that the value of the bonding strength of UF adhesive increases with nanoparticles $-0.5 \%$ and $1 \% \mathrm{SiO}_{2}$ at different moisture content of $0,12,18$ and $25 \%$. For example, the highest bonding strength value $\left(8.01 \mathrm{~N} / \mathrm{mm}^{2}\right)$ was acquired from the samples with wood moisture of $12 \%$ at $0.5 \%$ $\mathrm{SiO}_{2}$. At the same time, the addition of $0.5 \% \mathrm{TiO}_{2}$ was determined to have a good effect on adhesion strength for wood moisture of 12,18 and $25 \%$. On the other hand, $1 \% \mathrm{TiO}_{2}$ nanoparticles did not provide significant changes in adhesion strength for wood moisture of $0 \%$ and $25 \%$. It was reported that the poly(vinyl acetate) adhesive with 0.3 and $1.0 \%$ nanoparticles content

Table 4 Average and standard deviation values of bonding strength

Tablica 4. Prosječna vrijednost i standardna devijacija čvrstoće lijepljenja

\begin{tabular}{|c|c|c|}
\hline $\begin{array}{l}\text { Sample codes } \\
\text { Oznaka uzorka }\end{array}$ & $\begin{array}{c}\text { Moisture content } \\
\text { Sadržaj vode u } \\
\text { drvu } \\
\%\end{array}$ & $\begin{array}{c}\text { Bonding strength } \\
\check{C} \text { vrstoća lijepljenja } \\
\mathrm{N} / \mathrm{mm}^{2}\end{array}$ \\
\hline \multirow{4}{*}{ Pure UF } & 0 & $5.89(0.75)^{\mathrm{a}}$ \\
\hline & 12 & $6.17(0.89)$ \\
\hline & 18 & $5.75(1.12)$ \\
\hline & 25 & $4.99(0.89)$ \\
\hline \multirow{4}{*}{$0.5 \% \mathrm{SiO}_{2}+\mathrm{UF}$} & 0 & $6.99(1.09)$ \\
\hline & 12 & $8.01(0.81)$ \\
\hline & 18 & $7.86(1.19)$ \\
\hline & 25 & $7.72(1.32)$ \\
\hline \multirow{4}{*}{$1 \% \mathrm{SiO}_{2}+\mathrm{UF}$} & 0 & $6.44(0.65)$ \\
\hline & 12 & $7.99(1.45)$ \\
\hline & 18 & $7.91(1.30)$ \\
\hline & 25 & $7.19(1.27)$ \\
\hline \multirow{4}{*}{$0.5 \% \mathrm{TiO}_{2}+\mathrm{UF}$} & 0 & $5.37(0.99)$ \\
\hline & 12 & $7.07(1.35)$ \\
\hline & 18 & $6.67(1.20)$ \\
\hline & 25 & $6.34(1.15)$ \\
\hline \multirow{4}{*}{$1 \% \mathrm{TiO}_{2}+\mathrm{UF}$} & 0 & $5.09(0.67)$ \\
\hline & 12 & $7.83(0.95)$ \\
\hline & 18 & $7.23(1.08)$ \\
\hline & 25 & $5.15(0.50)$ \\
\hline
\end{tabular}

${ }^{a}$ Values in parentheses are sample standard deviations. / Vrijednost $i$ u zagradama standardne su devijacije. 
Table 5 Result of Duncan test

Tablica 5. Rezultati Duncanova testa

\begin{tabular}{|c|c|c|c|}
\hline $\begin{array}{l}\text { Sample codes } \\
\text { Oznaka uzorka }\end{array}$ & $\begin{array}{c}\text { Moisture } \\
\text { content } \\
\text { Sadržaj } \\
\text { vode u drvu } \\
\% \\
\end{array}$ & $\begin{array}{c}\text { Number } \\
\text { of samples } \\
\text { Broj } \\
\text { uzoraka }\end{array}$ & $\begin{array}{c}\text { Shear } \\
\text { strength } \\
\text { Smicajna } \\
\text { čvrstoća } \\
\mathrm{N} / \mathrm{mm}^{2}\end{array}$ \\
\hline Pure UF & 25 & 15 & $4.99 \mathrm{~A}$ \\
\hline $1 \% \mathrm{TiO}_{2}+\mathrm{UF}$ & 0 & 15 & $5.09 \mathrm{AB}$ \\
\hline $1 \% \mathrm{TiO}_{2}+\mathrm{UF}$ & 25 & 15 & $5.15 \quad \mathrm{AB}$ \\
\hline $0.5 \% \mathrm{TiO}_{2}+\mathrm{UF}$ & 0 & 15 & $5.37 \mathrm{ABC}$ \\
\hline Pure UF & 18 & 15 & $5.75 \mathrm{ABCD}$ \\
\hline Pure UF & 0 & 15 & $5.89 \mathrm{BCDE}$ \\
\hline Pure UF & 12 & 15 & 6.17 CDEF \\
\hline $0.5 \% \mathrm{TiO}_{2}+\mathrm{UF}$ & 25 & 15 & 6.34 DEFG \\
\hline $1 \% \mathrm{SiO}_{2}+\mathrm{UF}$ & 0 & 15 & 6.44 DEFGH \\
\hline $0.5 \% \mathrm{TiO}_{2}+\mathrm{UF}$ & 18 & 15 & $6.67 \mathrm{EFGH}$ \\
\hline $0.5 \% \mathrm{SiO}_{2}+\mathrm{UF}$ & 0 & 15 & 6.99 FGHI \\
\hline $0.5 \% \mathrm{TiO}_{2}+\mathrm{UF}$ & 12 & 15 & 7.07 GHIJ \\
\hline $1 \% \mathrm{SiO}_{2}+\mathrm{UF}$ & 25 & 15 & 7.19 GHIJK \\
\hline $1 \% \mathrm{TiO}_{2}+\mathrm{UF}$ & 18 & 15 & 7,23 HIJK \\
\hline $0.5 \% \mathrm{SiO}_{2}+\mathrm{UF}$ & 25 & 15 & 7.72 IJK \\
\hline $1 \% \mathrm{TiO}_{2}+\mathrm{UF}$ & 12 & 15 & 7.83 IJK \\
\hline $0.5 \% \mathrm{SiO}_{2}+\mathrm{UF}$ & 18 & 15 & $7.86 \quad$ IJK \\
\hline $1 \% \mathrm{SiO}_{2}+\mathrm{UF}$ & 18 & 15 & $7.91 \quad \mathrm{JK}$ \\
\hline $1 \% \mathrm{SiO}_{2}+\mathrm{UF}$ & 12 & 15 & $7.99 \mathrm{~K}$ \\
\hline $0.5 \% \mathrm{SiO}_{2}+\mathrm{UF}$ & 12 & 15 & $8.01 \mathrm{~K}$ \\
\hline
\end{tabular}

showed a higher bonding strength compared to that with pure adhesive in dry state (Peruzzo et al.,2014). The high surface area of nanoparticles increases the contact surface area with the adhesive resulting in strong adhesion between matrix and nanomaterial (Younesi-Kordkheili, 2017). Duncan test results obtained with the SPSS program are showed in Table 5.

With the rise of moisture content, the bonding strength of all adhesives increased to certain moisture content (12\%) and then started to decrease. Urea formaldehyde absorbs moisture when exposed to harsh environmental conditions (Biswas et al., 2011). Generally, the XRD analysis is used to determine the distribution of nanoparticles in the polymer matrix (Kaboorani and Riedl, 2011). Figures 4 and 5 show the XRD outcomes of UF resins reinforced with nanoparticles and nanoparticles $\left(\mathrm{TiO}_{2}, \mathrm{SiO}_{2}\right)$ prepared in this study.

Nanocomposites have three types of morphology: immiscible (conventional or micro composite), intercalated and exfoliated or miscible (Paul and Robeson, 2008). Exfoliated nanocomposites - In an exfoliated system, the individual nano-material layers are separated in a continuous polymer matrix by an average distance that depends on nanomaterial loading (Sinha Ray and Okamoto, 2003; Silvestre et al., 2016). Nano- $\mathrm{SiO}_{2}$ and nano$\mathrm{TiO}_{2}$ significant peaks are reduced in intensity or even disappeare, showing a high degree of intercalation and/ or exfoliation of the nanoparticle layers in UF polymer

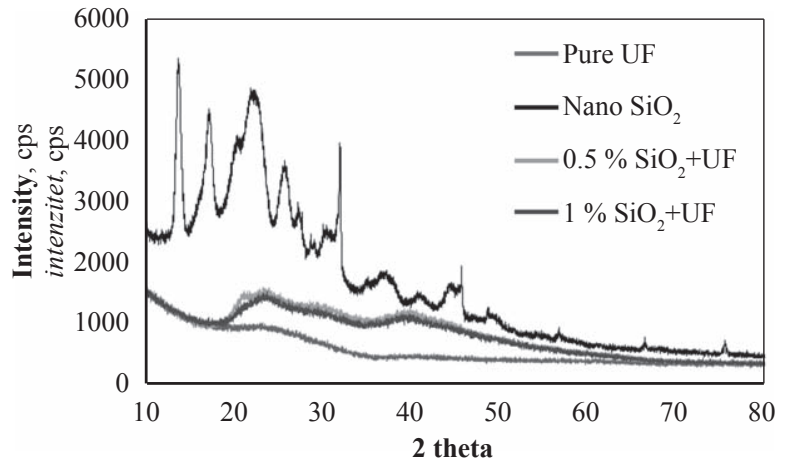

Figure $4 \mathrm{XRD}$ curves of neat UF and nano- $\mathrm{SiO}_{2}$ filled nanocomposites

Slika 4. XRD krivulje čistog urea-formaldehida i nanokompozita s punilom od nanočestica $\mathrm{SiO}_{2}$

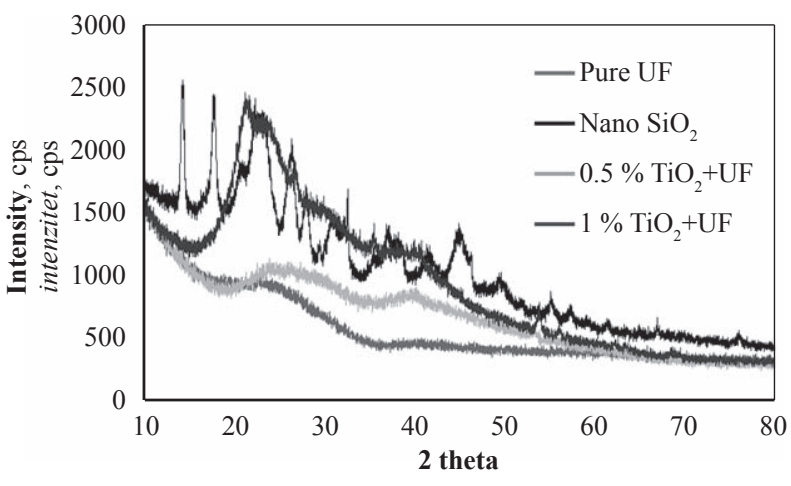

Figure $5 \mathrm{XRD}$ curves of neat UF and nano- $\mathrm{TiO}_{2}$ filled nanocomposites

Slika 5. XRD krivulje čistoga urea-formaldehida i nanokompozita s punilom od nanočestica $\mathrm{TiO}_{2}$

matrix (Hedayati and Arefazar, 2009; Zabarjad Shiraz et al., 2013). According to XRD test results, the nanoparticles dispersed in the polymer. This dispersion can be the reason for the increase in bonding strength of UF (Bardak et al., 2017).

Table 6 shows the effect of nanoparticles content on the viscosity of UF adhesives. Nano- $\mathrm{SiO}_{2}$ and nano$\mathrm{TiO}_{2}$ rise the viscosity of the UF adhesive in contrast with the pure UF adhesive. This can be explained by strong agglomeration tendency of nanomaterials (Veigel et al., 2011).

Studies have shown that, as the viscosity of UF adhesive increases, so does the adhesion bonding strength. This situation is explained by the increase of molecular weight and crosslink density of the nano/UF (Osemeohan et al., 2010).

Table 6 Effect of nanoparticles content on the viscosity of UF adhesives

Tablica 6. Utjecaj sadržaja nanočestica na viskoznost UF ljepila

\begin{tabular}{|l|c|}
\hline \multicolumn{1}{|c|}{$\begin{array}{c}\text { Sample codes } \\
\text { Oznaka uzorka }\end{array}$} & $\begin{array}{c}\text { Viscosity } \\
\text { Viskoznost }\end{array}$ \\
\hline Pure UF & $178 \mathrm{cP}$ \\
\hline $0.5 \% \mathrm{SiO}_{2}+\mathrm{UF}$ & $183 \mathrm{cP}$ \\
\hline $1 \% \mathrm{SiO}_{2}+\mathrm{UF}$ & $191 \mathrm{cP}$ \\
\hline $0.5 \% \mathrm{TiO}_{2}+\mathrm{UF}$ & $184 \mathrm{cP}$ \\
\hline $1 \% \mathrm{TiO}_{2}+\mathrm{UF}$ & $185 \mathrm{cP}$ \\
\hline
\end{tabular}


Table 7 Variation of gel time with nanoparticles Tablica 7. Promjena vremena geliranja ljepila s nanočesticama

\begin{tabular}{|l|c|}
\hline \multicolumn{1}{|c|}{$\begin{array}{c}\text { Sample codes } \\
\text { Oznaka uzorka }\end{array}$} & $\begin{array}{c}\text { Gel time } \\
\text { Vrijeme geliranja }\end{array}$ \\
\hline Pure UF & $94 \mathrm{sn}$ \\
\hline $0.5 \% \mathrm{SiO}_{2}+\mathrm{UF}$ & $90 \mathrm{sn}$ \\
\hline $1 \% \mathrm{SiO}_{2}+\mathrm{UF}$ & $94 \mathrm{sn}$ \\
\hline $0.5 \% \mathrm{TiO}_{2}+\mathrm{UF}$ & $92 \mathrm{sn}$ \\
\hline $1 \% \mathrm{TiO}_{2}+\mathrm{UF}$ & $96 \mathrm{sn}$ \\
\hline
\end{tabular}

Table 7 shows the variation of the gel time with nanoparticles. It is clear that the gel time values of the UF adhesive did not change significantly with nano$\mathrm{SiO}_{2}$ and nano- $\mathrm{TiO}_{2}$. This is in accordance with the literature (Dukarska and Czarnecki, 2016).

\section{CONCLUSIONS}

\section{ZAKLJUČAK}

The purpose of this study was to investigate the bonding performance of UF adhesives reinforced with nanoparticles. The results showed that the bonding strength of UF adhesive with $0.5-1 \%$ nano- $\mathrm{SiO}_{2}$ and $0.5 \%$ nano- $\mathrm{TiO}_{2}$ increase significantly when compared to that of pure UF adhesive at all moisture contents. On the other hand, there was no significant difference in 1 $\%$ nano- $\mathrm{TiO} 2$ in $0 \%$ and $25 \%$ moisture contents.

All samples with moisture content of $12 \%$ resulted in the highest bonding strength. Besides, the viscosity of UF adhesive increased with the nano- $\mathrm{SiO}_{2}$ and nano- $\mathrm{TiO}_{2}$ content. However, the addition of nanoparticles did not change gel time of the UF adhesive significantly. Consequently, it can be stated that nanoparticles could be beneficial in the development of more moisture-resistant UF adhesives.

\section{REFERENCES}

5. LITERATURA

1. Bardak, T.; Tankut, A. N.; Tankut, N.; Aydemir, D.; Sozen, E., 2017: The bending and tension strength of furniture joints bonded with polyvinyl acetate nanocomposites. Maderas. Ciencia y tecnología, 19 (1): 51-62. http://dx.doi.org/10.4067/S0718-221X2017005000005.

2. Bauer, F.; Mehnert, R., 2005: Uv curable acrylate nanocomposites: properties and applications. Journal of Polymer Research, 12: 483-491.

http://dx.doi.org/ 10.1007/s10965-005-4339-z.

3. Biswas, D.; Bose, K. S.; Hossain, M. M., 2011: Physical and mechanical properties of urea formaldehyde-bonded particleboard made from bamboo waste. International Journal of Adhesion \& Adhesives, 31: 84-87. http://dx.doi.org/ 10.1016/j.ijadhadh.2010.11.006.

4. Dorigato, A.; Pegoretti, A., 2011: The role of alumina nanoparticles in epoxy adhesives. Journal of Nanoparticle Research, 13: 2429-2441.

http://dx.doi.org/ 10.1007/s11051-010-0130-0.

5. Dukarska, D.; Czarnecki, R., 2016: Fumed silica as a filler for MUPF resin in the process of manufacturing water-resistant plywood. European of Journal of Wood and Wood Product, 74: 5-14.

http://dx.doi.org/10.1007/s00107-015-0955-4.
6. Ghosh, P. K.; Patel, A.; Kumar, K., 2016: Adhesive joining of copper using nano-filler composite adhesive. Polymer, 87: 159-169. https://doi.org/10.1016/j.polymer.2016.02.006.

7. Hedayati, A.; Arefazar, A., 2009: Multi-scale analysis of polypropylene based organoclay containing composites, Part 1: Morphology. Polymer Testing, 28: 128-138. https://doi.org/10.1016/j.polymertesting.2008.10.007.

8. Kwon, H. J.; Lee, S.-H.; Ayrilmis, N.; Han T. H., 2015: Tensile shear strength of wood bonded with urea-formaldehyde with different amounts of microfibrillated cellulose. International journal of Adhesion and Adhesives, 60: 88-91. https://doi.org/10.1016/j.ijadhadh.2015.04.002.

9. Kaboorani, A.; Riedl, B., 2011: Effects of adding nanoclay on performance of polyvinyl acetate (PVA) as a wood adhesive. Composites Part A: Applied Science and Manufacturing, 42: 1031-1039. https://doi.org/10.1016/j.compositesa.2011.04.007.

10. Katnam, K. B.; Comer, A. J.; Stanley W. F.; Buggy, M.; Ellingboe A. R.; Young, T. M., 2011: Characterising prepreg and non-crimp-fabric composite single lap bonded joints. International Journal of Adhesion \& Adhesives, 31: 679-686. https://doi.org/10.1016/j.ijadhadh.2011.06.013.

11. Lubis M. A. R.; Park B.-D.; Lee S.-M., 2017: Modification of urea-formaldehyde resin adhesives with blocked isocyanates using sodium bisulfite. International Journal of Adhesion \& Adhesives, 73: 118-124. https://doi.org/10.1016/j.ijadhadh.2016.12.001.

12. Mieloszyk, M.; Ostachowicz, W., 2017: Moisture contamination detection in adhesive bond using embedded FBG sensors. Mechanical Systems and Signal Processing, 84: 1-14.

https://doi.org/10.1016/j.ymssp.2016.07.006.

13. Osemeahon, S. A.; Nkafamiya, I. I.; Milam, C.; Modibbo, U. U., 2010: Utilization of amino resin for emulsion paint formulation: Effect of urea formaldehyde viscosity on urea formaldehyde and soybean oil copolymer composite. African Journal of Pure and Applied Chemistry, 4(1): 1-6.

14. Park, B.-D.; Lee S.-M.; Roh J.-K., 2009: Effects of formaldehyde/urea mole ratio and melamine content on the hydrolytic stability of cured urea-melamine-formaldehyde resin. European Journal of Wood and Wood Product, 67: 121-123. https://doi.org/10.1007/s00107-008-0277-x.

15. Paul. D. R.; Robeson, L. M., 2008: Polymer nanotechnology: Nanocomposites. Polymer (Guildf), 49: $3187-$ 3204. https://doi.org/10.1016/j.polymer.2008.04.017.

16. Peruzzo, P. J.; Bonnefond, A.; Reyes, Y.; Fernandez, M.; Fare, J.; Ronne, E.; Paulis, M.; Leiza, J. R., 2014: Beneficial in-situ incorporation of nanoclay to waterborne PVAc/ PVOH dispersion adhesives for wood applications. International Journal of Adhesion and Adhesives, 48: 295-302. https://doi.org/10.1016/j.ijadhadh.2013.09.042.

17. Salla, J.; Pandey, K. K.; Srinivas, K., 2012: Improvement of UV resistance of wood surfaces by using $\mathrm{ZnO}$ nanoparticles. Polymer Degradation and Stability, 97: 592-596. https://doi.org/10.1016/j.polymdegradstab.2012.01.013.

18. Silvestre, J.; Silvestre, N.; Brito, J. D., 2016: Polymer nanocomposites for structural applications: Recent trends and new perspectives. Mechanicsof Advanced Materials and Structures, 23: 1263-1277. htpp://dx.doi.org./10.1080/15376494.2015.1068406.

19. Ray S. S.; Okamoto, M., 2003: Polymer/layered silicate nanocomposites: a review from preparation to processing. Progress in Polymer Science, 28: 1539-1641. https://doi.org/10.1016/j.progpolymsci.2003.08.002. 
20. ***TS 2474, 1976: Wood-determination of ultimate strength in static bending. Turkish Standards Institution, Ankara, Turkey (in Turkish).

21. Veigel, S.; Muller, U.; Keckes, J.; Obersriebnig, M.; Gindl-Altmutter, W., 2011: Cellulose nanofibrils as filler for adhesives: effect on specific fracture energy of solid wood-adhesive bonds. Cellulose, 18: 1227-1237. https://doi.org/10.1007/s10570-011-9576-1.

22. Wang, Z.; Gu, Z.; Hong, Y.; Cheng, L.; Li, Z., 2011: Bonding strength and water resistance of starch-based wood adhesive improved by silica nanoparticles. Carbohydrate Polymers, 86: 72-76. https://doi.org/10.1016/j.carbpol.2011.04.003.

23. Yang, H.; Zhang, Q.; Guo, M.; Wang, C.; Du, C.; Fu, Q., 2006: Study on the phase structures and toughening mechanism in PP/EPDM/SiO2 ternary composites. Polymer, 47: 2106-2115. https://doi.org/10.1016/j.polymer.2006.01.076.

24. Younesi-Kordkheili, H., 2017: Improving physical and mechanical properties of new lignin- urea-glyoxal resin by nanoclay. European Journal of Wood and Wood Products, 1-7. https://doi.org/10.1007/s10570-011-9576-1.

25. Zabarjad Shiraz, N.; Enferad, E.; Monfared, A.; Mojarrad, M. A., 2013: Preparation of Nanocomposite Based on Exfoliation of Montmorillonite in Acrylamide Thermosensitive Polymer. ISRN Polymer Science, 1-5. http://dx.doi.org/10.1155/2013/280897.

\section{Corresponding address:}

Research Assistant ESER SÖZEN

Bartin University

Faculty of Forestry

Department of Forest Industrial Engineering

74100 Bartin, TURKEY

e-mail: esozen@bartin.edu.tr 